\title{
ANTINOMI PERATURAN PERUNDANG-UNDANGAN MENGENAI IMPOR GARAM NASIONAL
}

\author{
Laurensia Frida Alfiani \\ Fakultas Hukum, Universitas Gadjah Mada, Indonesia \\ Email: laurensiafrida95@mail.ugm.ac.id
}

\begin{abstract}
Abstrak
Tujuan dari penelitian ini adalah untuk mengkaji secara komprehensif normatif untuk menemukan solusi tepat demi menuntaskan masalah tata kelola garam khususnya impor garam nasional dan kesejahteraan petani garam di Indonesia. Pertentangan (Antinomi) perundang-undangan mengakibatkan kewenangan untuk memberikan rekomendasi impor garam menjadi tumpang tindih, ketidaksinkronan tujuan, dan pelemahan industri garam lokal. Antinomi yang dimaksud adalah antinomi antara Undang-Undang Nomor 7 Tahun 2016 tentang Perlindungan dan Pemberdayaan Nelayan, Pembudi Daya Ikan, dan Petambak Garam terhadap Peraturan Pemerintah Nomor 9 Tahun 2018 tentang Tata Cara Pengendalian Impor Komoditas Perikanan Dan Komoditas Pergaraman Sebagai Bahan Baku Dan Bahan Penolong Industri dan Peraturan Menteri Perdagangan Nomor 63 Tahun 2019 tentang Ketentuan Impor Garam. Swasembada garam yang menjadi program pemerintah dalam Rencana Pembangunan Jangka Menengah Tahun 20202024 sebagaimana telah diatur dalam Peraturan Presiden Nomor 18 Tahun 2020 menjadi hal mustahil jika antinomi peraturan perundang-undangan di bidang impor garam dibiarkan terus terjadi. Penelitian akan dilakukan dengan metode yuridis normatif untuk memaparkan fakta hukum berupa data sekunder yang terdiri dari bahan hukum primer dan bahan hukum sekunder. Data sekunder akan dianalisis menggunakan asas berlakunya perundang-undangan, teori antinomi dan ilmu perundang-undangan. Berdasarkan hasil penelitian menjelaskan bahwa penyelesaian antinomi hukum dilakukan dengan dua cara yakni penggunaan asas berlakunya perundang-undangan lex superior derogat legi inferior atau melalui upaya uji materiil kepada Mahkamah Agung.
\end{abstract}

\section{Kata kunci: Antinomi; Impor; Garam.}

\section{Abstract}

The purpose of this research is to examine comprehensively normatively to find the right solution to solve the problem of salt management, especially the national salt import and the welfare of salt farmers in Indonesia. The contradiction (antinomy) of the law has resulted in overlapping authority to provide recommendations for salt imports, asynchronization of objectives, and a weakening of the local salt industry. The intended antinomy is the antinomy between Law Number 7 of 2016 concerning Protection and Empowerment of Fishermen, Fish Farmers and Salt Farmers against Government Regulation Number 9 of 2018 concerning Procedures for Controlling Imports of Fishery Commodities and Salt Commodities as Raw Materials and Industrial Supporting Materials. and Regulation of the Minister of Trade Number 63 of 2019 concerning Provisions for Salt Imports. Selfsufficiency in salt, which is a government program in the 2020-2024 Mid-Term Development Plan as regulated in Presidential Regulation Number 18 of 2020, becomes impossible if the antinomies of the laws and regulations in the field of salt import are allowed to continue. The research will be conducted using the normative juridical method to explain legal facts in the form of secondary data consisting of primary and secondary legal materials. Secondary data will be analyzed using the principle of validity of legislation, antinomic theory and statutory science. Based on the results of the study, it was explained that the settlement of legal antinomies was carried out in two ways, namely the use of the principle of the enactment of the lex superior derogat legi inferior law or through material review efforts to the Supreme Court.

Key words: Antinomy; Import; Salt.

24 Laurensia Frida Alfiani | Antinomi Peraturan Perundang-Undangan... 


\section{A. PENDAHULUAN}

Pasal 25 Undang-Undang Dasar Negara Republik Indonesia Tahun 1945 menentukan bahwa Negara Kesatuan Republik Indonesia adalah sebuah negara kepulauan yang berciri Nusantara dengan wilayah dan batas-batas dan hak-haknya ditetapkan dengan undang-undang. Pasal tersebut memberi makna bahwa hak pengelolaan laut berdasarkan aspirasi masyarakat dan adanya kewenangan pengelolaan laut oleh pemerintah dan pemerintah daerah. Salah satu sumber daya kelautan yang dikelola pemerintah dan pemerintah daerah sesuai kewenangannya adalah garam. Garam merupakan salah satu komoditi penting yang berkaitan langsung dengan kehidupan manusia, baik digunakan untuk konsumsi maupun industri. Indonesia merupakan negara yang memiliki luas lautan lebih banyak sehingga sudah tentu menjadi negara yang bisa memproduksi garam sendiri bahkan mengekspor ke negara lain.

Pada tataran empiris, Indonesia pernah berjaya melakukan produksi garam melimpah pada tahun 2012-2015, bahkan pada tahun 2015 produksi surplus hingga 2,9 juta ton padahal kebutuhan nasional hanya 2 juta ton. Namun masalah terjadi pada awal 2017 produksi garam domestik menurun sehingga harus bergantung pada impor untuk kebutuhan garam industri. ${ }^{1}$ Faktor yang mempengaruhi adalah produksi garam di Indonesia menurun karena masih menggunakan cara pengolahan garam tradisional seperti ketergantungan cahaya matahi dan kurang menggunakan teknologi yang mutakhir. Faktor lain adalah kurangnya gudang penampungan dan lahan yang sempit sehingga kualitas kadar Natrium Clorida (NaCL) tidak sesuai standar internasional seperti yang dialami petambak garam di Cirebon Jawa Barat. ${ }^{2}$

Fakta empiris yang dihadapi oleh Petambak Garam memerlukan perlindungan dan pemberdayaan Nelayan, Pembudi Daya Ikan, dan Petambak Garam, termasuk keluarga Nelayan dan Pembudi Daya Ikan yang melakukan pengolahan dan pemasaran sehingga mendapatkan nilai tambah dari produksi garam, yang berujung pada swasembada garam nasional. Fakta sosiologis ini melatarbelakangi pengundangan Undang-Undang Nomor 7 Tahun 2016 tentang Perlindungan dan Pemberdayaan Nelayan, Pembudi Daya Ikan, dan Petambak Garam. Pengendalian impor garam menjadi kebijakan yang diatur dalam Pasal 37 Undang-Undang Nomor 7 Tahun 2016 tentang Perlindungan dan Pemberdayaan Nelayan, Pembudi Daya Ikan, dan Petambak Garam. Persyaratan impor seperti tempat pemasukan, jenis, waktu pemasukan, dan/atau standar mutu yang telah ditetapkan Menteri di bidang Kelautan dan Perikanan, mutlak harus dipenuhi bagi setiap orang atau badan usaha yang hendak melalukan impor garam.

Disatu sisi, petambak garam mendapatkan perlindungan dan pemberdayaan dari Pemerintah dan Pemerintah Daerah, serta larangan bagi Pemerintah dan Pemerintah Daerah untuk membuat kebijakan yang bertentangan dengan upaya Perlindungan dan Pemberdayaan Petambak Garam sebagaimana diatur dalam Undang-Undang Nomor 7 Tahun 2016 tentang Perlindungan Dan Pemberdayaan Nelayan, Pembudi Daya Ikan, dan Petambak Garam. Disisi lain, Petambak garam masih kesulitan untuk mendapatkan perlindungan dan pemberdayaan dikarenakan peraturan pelaksana impor garam yakni Peraturan Pemerintah Nomor 9 Tahun 2018 tentang Tata Cara Pengendalian Impor Komoditas Perikanan Dan Komoditas Pergaraman Sebagai Bahan Baku Dan Bahan Penolong Industri dan Peraturan Menteri Perdagangan Nomor 63 Tahun 2019 tentang Ketentuan Impor Garam yang membuka celah impor semakin lebar. Hal ini dikarenakan jenis garam yang diimpor yang semula hanya garam industri, saat ini semua garam dapat diimpor. Selain itu, peraturan pelaksana membuat kekacauan normatif karena

${ }^{1}$ M. Ambari, “https://www.mongabay.co.id/2017/08/29/bangkit-dari-keterpurukan-indonesia-targetkan-swasembadagaram-pada-2019-bagaimana-strateginya/", diakses 03 November 2020.

${ }^{2}$ M. Ambari, "https://www.mongabay.co.id/2018/04/30/garam-rakyat-didorong-penuhi-standar-internasional-bagaimanacaranya/", diakses 03 November 2020. 
menambah kewenangan memberikan rekomendasi impor pada Menteri Perdagangan dan Menteri Peindustrian.

Penelitian ini akan memaparkan konflik antar peraturan perundang-undangan (antinomi) di bidang impor garam. Antinomi ini berimplikasi krusial pada lemahnya perlindungan petambak garam dan berkurangnya produksi garam nasional. Dengan demikian petani garam berada diposisi yang sangat dirugikan, sehingga diperlukan suatu kajian khusus secara komprehensif normatid $\mathrm{m}$ untuk menemukan solusi tepat demi menuntaskan masalah tata kelola garam khususnya impor garam nasional dan kesejahteraan petani garam di Indonesia.

\section{B. METODE PENELITIAN}

Metode penelitian hukum yang digunakan adalah normatif. Dalam penelitian ini, metode yang digunakan adalah library research atau penelitian kepustakaan. Penelitian semacam ini lazim disebut legal research atau legal reseacrh instruction. ${ }^{3}$ Fokus penelitian ini berdasarkan pada peraturan perundang-undangan mengenai Impor Garam Nasional . Data yang dipergunakan merupakan data sekunder, dengan proses berpikir secara deduktif. Dalam penelitian hukum normatif hukum yang tertulis dikaji dari berbagai aspek seperti aspek teori, filosofi, perbandingan, struktur/komposisi, konsistensi, penjelasan umum dan penjelasan pada tiap pasal, formalitas dan kekuatan mengikat suatu undang-undang seta bahasa yang digunakan adalah bahasa hukum. Sehingga dapat disimpulkan bahwa pada penelitian hukum normatif mempunyai cakupan yang luas.

Sumber data yang digunakan dalam penelitian hukum normatif ini adalah data sekunder yaitu data yang diperoleh dari bahan-bahan pustaka. Data sekunder yang digunakan antara lain, Bahan hukum primer berupa peraturan perundang-undangan yang berkaitan dengan kajian Impor garam nasional seperti Undang-Undang Dasar Negara Republik Indonesia Tahun 1945, Undang-Undang Nomor 7 Tahun 2016 tentang Perlindungan dan Pemberdayaan Nelayan, Pembudi Daya Ikan, dan Petambak Garam, Peraturan Menteri Kelautan Dan Perikanan Nomor 66/PERMEN-KP/2017 tentang Pengendalian Impor Komoditas Pergaraman, Peraturan Pemerintah Nomor 9 Tahun 2018 tentang Tata Cara Pengendalian Impor Komoditas Perikanan Dan Komoditas Pergaraman Sebagai Bahan Baku Dan Bahan Penolong Industri dan Peraturan Menteri Perdagangan Nomor 63 Tahun 2019 tentang Ketentuan Impor Garam. Pendekatan yang dapat digunakan adalah pendekatan perundang-undangan (Statute Approach) dan pendekatan konsep (conceptual approach). ${ }^{4}$

\section{PEMBAHASAN}

\section{Teori antinomi dan antinomi hukum}

Istilah antinomi telah dikenal sejak tradisi hukum Yunani kuno dengan istilah "antinomia", untuk menunjukan adanya pertentangan dalam diri suatu hukum. Konsep antinomi dipandang sebagai sebuah kursus dalam pemikiran filsafat, khususnya filasafat hukum, yang dikembangkan oleh Immanuel Kant. Sebelum Kant, David Hume mengenalkan konsep antinomi yaitu sebuah konsep pertentangan yang selalu ada dalam suatu materi atau prinsip. ${ }^{5}$ Lebih lanjut diuraikan

As thus dilemma is an evident consequence of the priciple, that every idea arises from a similar impression, so our decision betwixt the propositions of the dilemma is ni more doubtful go far from there being any distinct impression, attending every impression and every idea, that I do not think there are any two distinct impression which are inseparably conjoined. 23.

${ }^{3}$ Soerjono Soekanto dan Sri Mamudji. (2006). Penelitian Hukum Normatif Tinjauan Singkat. Jakarta: Rajawali Press, hlm

${ }^{4}$ Johny Ibrahim, Teori dan Metodologi Penelitian Hukum Normatif (Malang: Banyumedia Publishing, 2006), hlm. 300

${ }^{5}$ David Hume. (2009). A Treaties of Human Nature. Auckland: The Floating Press, hlm 115.

26 Laurensia Frida Alfiani | Antinomi Peraturan Perundang-Undangan... 
Dari konsep Hume, Kant mengembangkan struktur formal tentang antinomi di dalam pemikiran filsafat atau disebut lima gagasan. Antinomi pertama terdiri dari dua bagian. Struktur formal antinomi digambarkan Kant dalam tabel berikut ${ }^{6}$ :

Tabel 1. Struktur Formal Antinomi

\begin{tabular}{|r|r|r|}
\hline Antinomy & Given & R-condition \\
\hline First (time) & State of the world & Precedes \\
\hline First (space) & Spatial world religion & Properly encloses \\
\hline Second & Composite body & Is a (proper) part of \\
\hline Third & Alteration & $\begin{array}{r}\text { Grounds the causal power } \\
\text { producing }\end{array}$ \\
\hline Fourth & Alteration & Grounds the (contingent) exis- \\
tence of
\end{tabular}

Keempat struktur formal dijabarkan Kant untuk mengajukan pertanyaan mendasar sebagai berikut:

a. Does the world have a beginning in time? A limit space?

b. Is matter composed of simple substances of divisible to infinity?

c. Does the causality producing any event in nature depend on a spontaneous cause beyond nature?

d. Is nature for any part of it necessarily existent?

Antinomi pertama berfokus pada pembatasan dunia yang terbatas ruang dan waktu. Keterbatasan ruang itulah yang memberikan institusi murni, sebagai sesuatu yang sangat penting dan tanpa batas, tetapi dibatasi oleh pertanyaan untuk apa sesunguhnya dunia?. Disisi lain, antinomi kedua mendasarkan pada kategori kualitas atau komposisi substansi materi. Antinomi ketiga berada dalam pandangan hubungan sebab akibat antara satu materi dengan materi lainnya, yang semuanya membentuk keteraturan. Antinomi keempat adalah gagasan kesadaran adanya kebutuhan (the existence of a necessary being).

Kant ingin memberikan analisis mengenai dunia yang tampak pada kesadaran manusia. Manusia memiliki emosi yang mdijadikan suatu pengertian melalui bentuk ruang dan waktui. Pengertian tersebut kemudian menjadi pengalaman yang terkategorisasi menjadi susbstansi, kualitas, dan kausalitas. Pengalaman tersebut kemudian dinilai dan dihubungkan satu sama lain melalui prinsip-prinsip umum. Kant mengemukakan pendapat ini karena disasarkan pada pertentangan fundamental antara akal dan alam. Alam dipandang selalu mengikuti kebutuhan, sedangkan akal manusia cenderung bebas karena manusia dapat menentukan tujuannya sendiri melalui kehendak bebas.

Gagasan mengenai antinomi yang dikemukakan Hume dan Kant kemudian berkembang di dalam teori hukum. Dalam teori hukum, antinomu dikenal sebagai suatu pertentangan norma di dalam suatu peraturan perundang-undangan. Friedmann berpendapat bahwa pertentanganpertentangan terjadi sebagai akibat dari posisi alamiah hukum itu sendiri, yang berdiri di antara nalar filsafat, dan kebutuhan politik praktis. Kategori-kategori intelektual hukum dibangun dari penalaran filsafat yang panjang dan holistik, sedangkan cita-cita keadilan di dalam hukum dikonstruksikan melalui sebuah mekanisme politik yang cenderung transaksional. Hal ini berakibat pada hukum bukanlah sesuatu yang terjadi secara alamiah, melainkan merupakan hasil dari beraneka ragamnya proses internalisasi, intrusi, dan negosiasi berbagai kepentingan diantara faksi-faksi dan aktor-aktor dalam masyarakat.

Gustav Radbruch menjelaskan bahwa cita hukum (idee des rechts) yang dilembagakan dalam suatu bentuk negara hukum, dapat diklasifikasikan ke dalam tiga prinsip yaitu:

\footnotetext{
${ }^{6}$ Immanuel Kant. (2010). Critique of Pure Reason. Cambridge University Press, hlm. 251.
} 
kemanfaatan (purposiveness, Zweckmassigkeit), keadilan (justice, Gerechtigkeit), dan kepastian hukum (legal certainty, Rechtssicherheit). Ketiga unsur tersebut seharusnya terdapat dalam hukum, baik peraturan perundang-undangan maupun putusan hakim, secara proporsional dan berimbang. Semua unsur harus terakomodasi atau tidak boleh ada unsur yang diabaikan. Faktanya, hukum yang benar-benar proporsional masih sulit untuk diwujudkan. Hal tersebut dikarenakan cita hukum yang satu dengan yang lain memiliki nilai-nilai yang saling bertentangan-kontradiksi (antinomi), sebagai contoh antara unsur kepastian dan keadilan.

Sudikno Mertokusumo berpendapat, dengan merujuk pada pandangan Scholten, bahwa dalam kondisi tertentu, antinomi dalam hukum juga berkaitan dengan asas hukum yang bersifat umum. Asas hukum tidak hanya asas yang berkaitan dengan waktu dan tempat, melainkan juga asas hukum yang tidak terpengaruh waktu dan tempat. Lima asas hukum umum yang dimaksud adalah asas kepribadian, asas persekutuan, asas kesamaan, asas kewibawaan, dan asas pemisahan baik dan buruk. Empat asas pertama senantiasa terdapat dalam sistem hukum, meskipun saling bertentangan satu dengan yang lainnya, yaitu antara asas kepribadian dengan asas persatuan, dan asas kesamaan dengan asas kewibawaan. Semua sistem hukum mengenal keempat asas tersebut. Meskipun tidak semua sistem hukum menerapkan keempat asas tersebut secara penuh, setiap sistem hukum tetap menerapkan keempat asas dengan kecenderungan ke beberapa asas tertentu.

Positivisme dan ideliasme juga merupakan suatu antinomi dalam teori hukum. Pengikut aliran positivisme berpendapat bahwa hukum harus ditentukan atau dirumuskan berdasarkan permasalahan yang dihadapi. Keberadaan suatu peraturan hukum disebabkan oleh adanya kebutuhan untuk menyelesaikan atau mengatur suatu persoalan tertentu, sehingga proses pembentukan hukum seperti hubungan sebab akibat, dengan kondisi yang dihadapi. Sedangkan, pengikut aliran idealiasme melahirkan hukum yang berasal dari prinsip-prinsip dasar, yang diambil dari nilai-nilai manusia sebagai makhluk yang memiliki rasio dan etika, tidak hanya berdasarkan persoalan yang dihadapi sehari-hari. Teori idelisme hukum bertujuan untuk menciptakan aturan-aturan apa yang seharusnya dilakukan dan apa yang seharusnya tidak boleh dilakukan oleh manusia, agar tercipta kehidupan yang memberikan jaminan terhadap kepentingan-kepentingan manusia itu sendiri.

\section{Antinomi peraturan perundang-undangan tentang impor garam nasional}

Pasal 1 angka 3 Peraturan Pemerintah Nomor 9 Tahun 2019 tentang Tata Cara Pengendalian Impor Komoditas Perikanan Dan Komoditas Pergaraman Sebagai Bahan Baku Dan Bahan Penolong Industri menentukan bahwa garam adalah senyawa kimia yang komponen utamanya berupa natrium klorida dan dapat mengandung unsur lain, seperti magnesium, kalsium, besi, dan kalium dengan bahan tambahan atau tanpa bahan tambahan iodium. Garam merupakan komoditas yang menjadi sasaran pembangunan guna mewujudkan kemandirian di sektor ekonomi. Rencana Pembangunan Jangka Menengah Nasional (RPJMN) Tahun 2020-2024 sebagaimana telah diatur dalam Peraturan Presiden Nomor 18 Tahun 2020, menentukan bahwa Pemerintah Indonesia ingin mewujudkan kemandirian ekonomi dengan menggerakan sektorsektor strategis ekonomi domestik, salah satunya dengan peningkatan kedaulatan sektor garam.

Pemerintah menargetkan mampu meningkatkan produksi garam sebanyak 3 juta ton di tahun 2020, 3,1 juta ton di tahun 2021, 3,2 juta ton di tahun 2022, 3,3 juta ton di tahun 2023, dan 3,4 juta ton di tahun 2024. Peningkatan produksi garam yang dapat dilakukan Pemerintah Pusat adalah dengan memfasilitasi lahan garam, membangun sarana niaga garam rakyat, dan pengadaan sarana-prasarana tambak garam. 
Proyek prioritas yang akan dilaksanakan pada tahun 2020-2024 terkait pergaraman adalah Pengembangan komoditas unggulan Wilayah Nusa Tenggara yaitu: kelapa, lada, pala, cengkeh, kopi, tebu, garam, tembaga, emas, perikanan budidaya, dan perikanan tangkap, dengan fokus komoditas yaitu:

a. Provinsi Nusa Tenggara Barat: kelapa, kopi, tebu, garam, tembaga, emas, perikanan budidaya, dan perikanan tangkap; dan

b. ProvinsiNusa Tenggara Timur:kopi, kelapa, lada, pala, cengkeh, tebu, garam, dan perikanan budidaya.

Wilayah Indonesia timur menjadi fokus pengembangan komoditas garam karena ketersediaan lahan yang cukup bagi pengembangan.

Sasaran peningkatan kedaultan garam diwujudkan dengan memberikan perlindungan dan pemberdayaan petambak garam. Pasal 3 Undang-Undang Nomor 7 Tahun 2016 tentang tentang Perlindungan dan Pemberdayaan Nelayan, Pembudi Daya Ikan, dan Petambak Garam menyebutkan bahwa tujuan Perlindungan dan Pemberdayaan Nelayan, Pembudi Daya Ikan, dan Petambak Garam adalah:

a. Menyediakan prasarana dan sarana yang dibutuhkan dalam mengembangkan usaha;

b. Memberikan kepastian usaha yang berkelanjutan;

c. Meningkatkan kemampuan dan kapasitas Nelayan, Pembudi Daya Ikan, dan Petambak Garam;

d. menguatkan kelembagaan dalam mengelola sumber daya Ikan dan sumber daya kelautan serta dalam menjalankan usaha yang mandiri, produktif, maju, modern, dan berkelanjutan; dan mengembangkan prinsip kelestarian lingkungan;

e. Menumbuhkembangkan sistem dan kelembagaan pembiayaan yang melayani kepentingan usaha;

f. Melindungi dari risiko bencana alam, perubahan iklim, serta pencemaran;

g. Memberikan jaminan keamanan dan keselamatan serta bantuan hukum.

Berdasarkan tujuan pembentukan Undang-Undang Nomor 7 Tahun 2016 tentang Perlindungan dan Pemberdayaan Nelayan, Pembudi Daya Ikan, dan Petambak Garam, memberikan kewenangan kepada pemerintah pusat dan pemerintah daerah untuk penyelenggaraan perlindungan bagi petambak garam.

Pasal 16 ayat (1) Undang-Undang Nomor 7 Tahun 2016 tentang Perlindungan dan Pemberdayaan Nelayan, Pembudi Daya Ikan, dan Petambak Garam, menyatakan bahwa Pemerintah Pusat sesuai dengan kewenangannya bertanggung jawab atas Perlindungan Nelayan, Pembudidaya Ikan, dan Petambak Garam. Pelaksanaan perlindungan ini dilakukan dengan beberapa strategi sebagaimana diatur dalam Pasal 12 ayat (2) Undang-Undang Nomor 7 Tahun 2016 tentang Perlindungan dan Pemberdayaan Nelayan, Pembudi Daya Ikan, dan Petambak Garam. Adapun strategi perlindungan tersebut dilakukan melalui:

a. Penyediaan prasarana usaha pergaraman;

b. Kemudahan memperoleh sarana usaha pergaraman;

c. Jaminan kepastian usaha;

d. Jaminan risiko pergaraman;

e. Penghapusan praktik ekonomi biaya tinggi;

f. Pengendalian impor komoditas pergaraman;

g. Jaminan keamanan dan keselamatan; dan

h. Fasilitasi dan bantuan hukum.

Pasal 12 ayat (3) Undang-Undang Nomor 7 Tahun 2016 tentang Perlindungan dan Pemberdayaan Nelayan, Pembudi Daya Ikan, dan Petambak Garam, diuraikan juga tentang strategi pemberdayaan dilakukan melalui: 
a. pendidikan dan pelatihan;

b. penyuluhan dan pendampingan;

c. kemitraan usaha;

d. kemudahan akses ilmu pengetahuan, teknologi, dan informasi; dan

e. penguatan Kelembagaan.

Kewenangan yang hanya dimiliki Pemerintah Pusat (Pemerintah Daerah tidak memiliki kewenangan) adalah mengenai impor garam. Berdasarkan undang-undang ini pula, diatur penghapusan praktik ekonomi biaya tinggi dan pengendalian impor komoditas pergaraman. Pasal 36 Undang-Undang Nomor 7 Tahun 2016 tentang Perlindungan dan Pemberdayaan Nelayan, Pembudi Daya Ikan, dan Petambak Garam, mengatur terkait penghapusan praktik ekonomi biaya tinggi yang dilakukan dengan membebaskan biaya penerbitan perizinan yang terkait dengan penangkapan ikan, pembudidayaan ikan, pengolahan, dan pemasaran; dan usaha pergaraman bagi nelayan kecil, pembudidaya ikan kecil, atau petambak garam kecil, termasuk keluarga nelayan dan pembudidaya ikan yang melakukan pengolahan dan pemasaran, membebaskan pungutan usaha perikanan atau usaha pergaraman, baik berupa pajak maupun retribusi bagi nelayan kecil, pembudi daya Ikan Kecil, atau petambak garam kecil, termasuk keluarga nelayan dan pembudi daya ikan yang melakukan pengolahan dan pemasaran.

Komitmen Pemerintah dan Pemerintah Daerah untuk memberikan perlindungan dan memberdayakan petambak garam dapat dilihat dari kebijakan pengendalian impor garam. Pengendalian impor diatur dalam Pasal 37 ayat (1) Undang-Undang Nomor 7 Tahun 2016 tentang Perlindungan dan Pemberdayaan Nelayan, Pembudi Daya Ikan, dan Petambak Garam, bahwa pemerintah pusat mengendalikan impor komoditas pergaraman. Lebih lanjut, Pasal 37 ayat (2) menyebutkan bahwa Pengendalian impor Komoditas Perikanan dan Komoditas Pergaraman dilakukan melalui penetapan tempat pemasukan, jenis dan volume, waktu pemasukan, serta pemenuhan persyaratan administratif dan standar mutu. Pasal 37 ayat (2), jika ditafsirkan secara teleologis atau kemanfaatan, dimaksudkan agar impor garam tidak dilakukan berdekatan dengan musim panen garam rakyat karena akan berdampak terhadap turunnya harga garam di tingkat masyarakat.

Namun, Undang-Undang Nomor 11 Tahun 2020 tentang Cipta Kerja mengganti ketentuan pasal 37 ayat (2) yang semula mengatur tentang penetapan tempat, jenis dan volume, waktu pemasukan, serta pemenuhan persyaratan administratif dan standar mutu, serta ayat (3) yang semula mengatur syarat rekomendasi Menteri Kelautan dan Perikanan, diganti menjadi pedelegasian pengaturan lebih lanjut mengenai impor pergaraman dengan sebuah Peraturan Pemerintah. Antara Pasal 38 dan Pasal 39 Undang-Undang Nomor 7 Tahun 2016 tentang Perlindungan dan Pemberdayaan Nelayan, Pembudi Daya Ikan, dan Petambak Garam disipkan Pasal 38A oleh Undang-Undang Nomor 11 Tahun 2020 dengan menambah ketentuan sanksi administratif bagi Setiap Orang yang melakukan impor Komoditas Perikanan dan Komoditas Pergaraman yang tidak sesuai dengan tempat pemasukan, jenis, waktu pemasukan, dan/atau standar mutu wajib yang ditetapkan oleh Pemerintah.

Perlindungan terhadap Petambak Garam dalam Undang-Undang Nomor 7 Tahun 2016 tentang Perlindungan dan Pemberdayaan Nelayan, Pembudi Daya Ikan, dan Petambak Garam dijabarkan oleh Menteri Kelautan dan Perikanan melalui Peraturan Pemerintah Kelautan dan Perikanan Nomor 66/PERMEN-KP/2017 tentang Pengendalian Impor Komoditas Pergaraman, yang memperhatikan penyerapan garam hasil produksi petambak garam. Pasal 8 ayat (1) Peraturan Pemerintah Kelautan dan Perikanan Nomor 66/PERMEN-KP/2017 menentukan bahwa Importir Garam wajib memprioritaskan penyerapan garam hasil produksi Petambak Garam yang tersedia untuk pemenuhan kebutuhan dalam negeri.

30 Laurensia Frida Alfiani | Antinomi Peraturan Perundang-Undangan... 
Bagan 1. Mekanisme Impor Garam

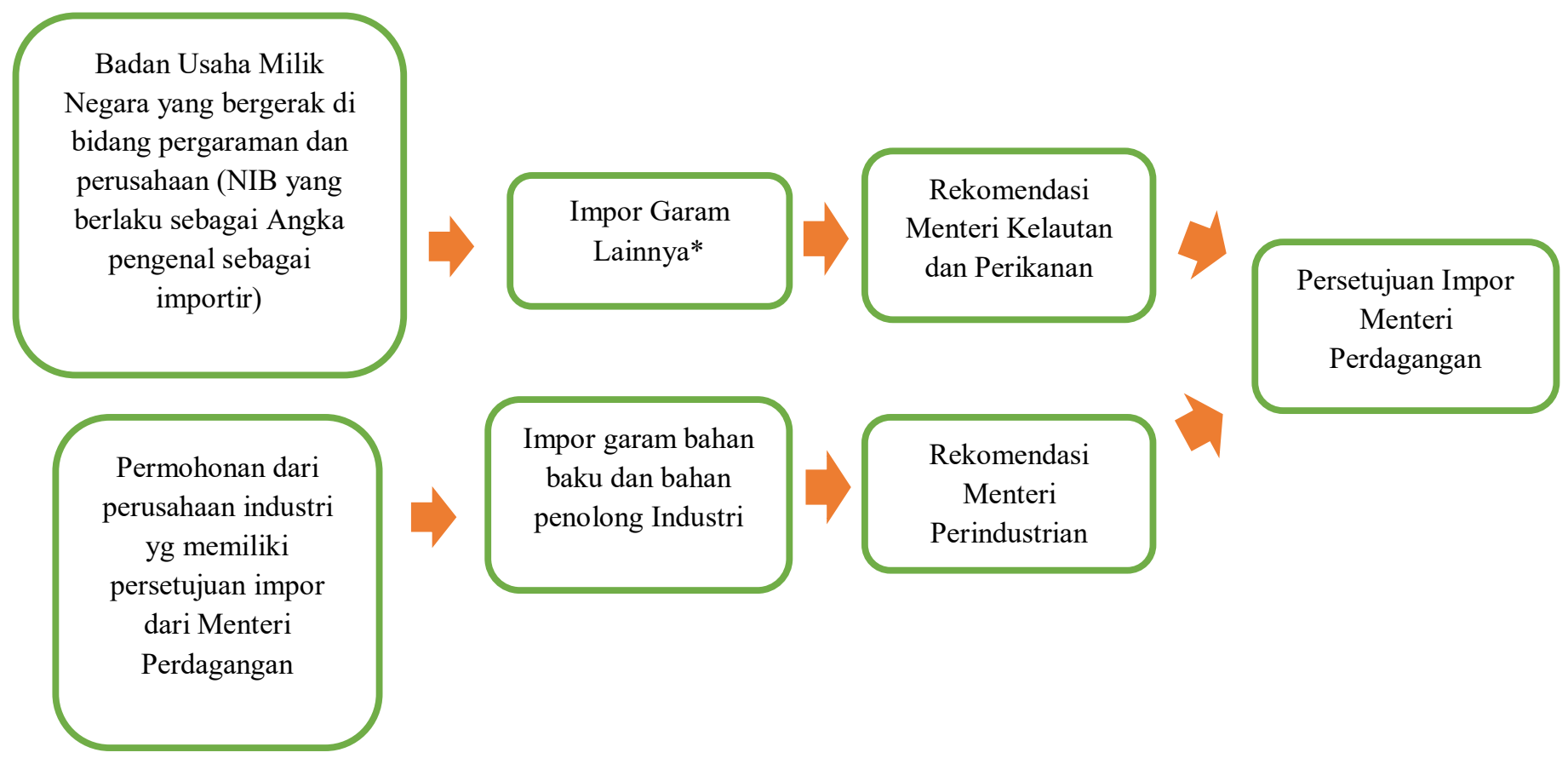

Keterangan: Yang dimaksud garam lainnya adalah: garam meja, Garam batu tidak diproses, garam lain-lain dengan kandungan natrium klorida lebih dari 60\% tetapi kurang dari 97\%, dihitung dari basis kering, diperkaya dengan yodium)

Pengaturan lebih lanjut mengenai kebijakan pengendalian impor garam diatur dengan Peraturan Pemerintah Nomor 9 Tahun 2018 tentang Tata Cara Pengendalian Impor Komoditas Perikanan dan Komoditas Pergaraman sebagai Bahan Baku dan Bahan Penolong Industri. Pengendalian komoditas pergaraman tersebut dilakukan melalui penetapan tempat pemasukan, jenis dan volume, waktu pemasukan, serta pemenuhan persyaratan administratif dan standar mutu sebagaimana diatur dalam Pasal 2 ayat (3) Peraturan Pemerintah Nomor 9 Tahun 2018 tentang Tata Cara Pengendalian Impor Komoditas Perikanan dan Komoditas Pergaraman sebagai Bahan Baku dan Bahan Penolong Industri.

Impor garam berdasarkan ketentuan Undang-Undang Nomor 7 Tahun 2016 tentang Perlindungan dan Pemberdayaan Nelayan, Pembudi Daya Ikan, dan Petambak Garam dan Peraturan Pemerintah Nomor 9 Tahun 2018 tentang Tata Cara Pengendalian Impor Komoditas Perikanan dan Komoditas Pergaraman sebagai Bahan Baku dan Bahan Penolong Industri harus dilakukan berdasarkan rekomendasi dari Menteri di bidang kelautan dan perikanan (garam meja, Garam batu tidak diproses, garam lain-lain dengan kandungan natrium klorida lebih dari 60\% tetapi kurang dari 97\%, dihitung dari basis kering, diperkaya dengan yodium) dan Menteri di bidang perindustrian (untuk garam bahan baku dan bahan penolong industri). Rekomendasi dari Menteri di bidang perindustrian untuk melakukan impor garam bahan baku dan bahan penolong industri harus memuat penetapan:

a. tempat pemasukan;

TempatpemasukanKomoditasPergaraman ditetapkan denganmempertimbangkanlokasi Industri sesuai dengan kebutuhan.

b. jenis;

Jenis Komoditas Pergaraman merupakan jenis Komoditas Pergaraman yang digunakan sebagai Bahan Baku dan bahan penolong Industri. 
c. volume;

Volume Komoditas Pergaraman ditetapkan berdasarkan hasil rapat koordinasi yang diselenggarakan oleh kementerian yang menyelenggarakan urusan pemerintahan di bidang koordinasi perekonomian.

d. waktu pemasukan;

waktupemasukanditetapkanberdasarkanhasilrapatkoordinasiyangdiselenggarakanoleh kementerianyangmenyelenggarakanurusanpemerintahandibidangkoordinasiperekonomian. e. standar mutu

StandarmutuKomoditas Pergaramanmemilikikandungannatriumklorida 97\%(sembilan puluh tujuh persen) atau lebih tetapi kurang dari 100\% (seratus persen) dihitung dari basis kering. Oleh karena itu, garam untuk kebutuhan bahan baku dan penolong industry yang dapat diimpor adalah garam yang memiliki kandungan natrium klorida 97\% (sembilan puluh tujuh persen) atau lebih tetapi kurang dari 100\% (seratus persen) dihitung dari basis kering. Setelah mendapatkan rekomendasi dari Menteri di bidang perindustrian untuk melakukan impor garam bahan baku dan bahan penolong industri, Menteri di bidang Perdagangan memberikan persetujuan impor, sebagaimana diatur Pasal 6 Peraturan Pemerintah Nomor 9 Tahun 2018 tentang Tata Cara Pengendalian Impor Komoditas Perikanan dan Komoditas Pergaraman sebagai Bahan Baku dan Bahan Penolong Industri. Persetujuan impor tidak terbatas pada impor garam untuk bahan baku dan bahan penolong industri, tetapi juga mencakup Garam selain untuk pemenuhan bahan baku dan bahan penolong industri sebagaimana diatur dalam Pasal 2 ayat (3) Peraturan Menteri Perdagangan Nomor 63 Tahun 2019 tentang Ketentuan Impor Garam.

Persoalan kewenangan untuk menerbitkan rekomendasi impor garam adalah UndangUndang Nomor 7 Tahun 2016 tentang Perlindungan dan Pemberdayaan Nelayan, Pembudi Daya Ikan, dan Petambak Garam hanya menentukan Menteri di bidang Kelautan dan Perikanan yang berwenang memberikan rekomendasi impor, sedangkan Peraturan Pemerintah Nomor 9 Tahun 2018 tentang Tata Cara Pengendalian Impor Komoditas Perikanan dan Komoditas Pergaraman sebagai Bahan Baku dan Bahan Penolong Industri membagi kewenangan untuk memberikan rekomendasi impor yakni Menteri di bidang Kelautan Perikanan dan Menteri Perindustrian. Lebih lanjut, Peraturan Pemerintah Nomor 9 Tahun 2018 tentang Tata Cara Pengendalian Impor Komoditas Perikanan dan Komoditas Pergaraman sebagai Bahan Baku dan Bahan Penolong Industri memberikan kewenangan kepada Menteri di bidang perdagangan untuk memberikan persetujuan impor untuk garam bahan baku dan bahan penolong, yang sebelumnya tidak diatur dalam Undang-Undang Nomor 7 Tahun 2016 tentang Perlindungan dan Pemberdayaan Nelayan, Pembudi Daya Ikan, dan Petambak Garam. Peraturan Menteri Perdangan Nomor 63 Tahun 2019 tentang Ketentuan Impor Garam juga telah memberikan kewenangan baru kepada Menteri di bidang Perdangan untuk memberikan persetujuan impor untuk garam selain untuk pemenuhan bahan baku dan bahan penolong industri yang sebelumnya belum pernah diatur dalam Undang-Undang Nomor 7 Tahun 2016 tentang Perlindungan dan Pemberdayaan Nelayan, Pembudi Daya Ikan, dan Petambak Garam.

Ketiga jenis peraturan perundangan-undangan mengalami pertentangan. Peraturan pemerintah dan Peraturan Menteri sudah melampaui batas jangkauan materi muatan pengaturan yakni menciptakan norma baru yang tidak pernah diamanatkan oleh peraturan otonom (undang-undang). Peraturan Pemerintah menambah kewenangan baru tanpa diperintahkan oleh undang-undang. Sebagaimana ditentukan Pasal 5 ayat (2) Undang-Undang Dasar Negara Republik Indonesia Tahun 1945, Peraturan Pemerintah dibentuk untuk menjalankan undangundang sebagaimana mestinya. Produk hukum Peraturan Pemerintah di bentuk oleh Presiden dalam rangka melaksanakan undang-undang. Dalam konsep hukum, peraturan pemerintah 
ditetapkan sebagai delegated legislation (peraturan pelaksanaan), yang ketentuannya hanya melaksanakan ketentuan undang-undang. ${ }^{7}$

Karakteristik Peraturan Pemerintah adalah ${ }^{8}$ :

a. Peraturan Pemerintah tidak dapat lebih dulu dibentuk tanpa ada undang-undang yang menjadi induknya;

b. Peraturan Pemerintah tidak dapat mencantumkan sanksi pidana apabila undang-undang yangbersangkutan tidak mencantumkan sanksi pidana;

c. KetentuanPeraturanPemerintahtidakdapatmenambahataumengurangiketentuanundangundang yang bersangkutan;

d. Peraturan Pemerintah dapat dibentuk meski ketentuan UU yang bersangkutan tidak memintanya secara tegas;

e. Ketentuan-ketentuan Peraturan Pemerintah berisi peraturan atau gabungan peraturan dan penetapan.

f. Peraturan Pemerintah tidak berisi penetapan semata-mata

Dengan demikian, Peraturan Pemerintah berisi pengaturan lebih lanjut dari undang-undang semata. Pernyataan ini didukung oleh pendapat J.A.H Logemann yang mengatakan Dit is een zeer ruime bevoegheid, maar het moet uitvoering blijven, geen aan vulling (ini adalah suatu kewenangan yang sangat luas, tetapi ia (peraturan pemerintah) harus tetap sebagai pelaksana belaka, tidak ada penambahan). ${ }^{9}$

Selain itu, peraturan menteri lahir karena urusan tertentu dalam pemerintahan yakni urusan -urusan yang telah menjadi urusan kementerian itu sendiri dan urusan yang telah ditetapkan oleh peraturan perundang-undangan baik undang-undang, peraturan pemerintah maupun peraturan presiden. Meskipun demikian tidak semua kementerian mempunyai kewenangan untuk membentuk peraturan menteri, hanya menteri-menteri yang memimpin suatu lembaga saja yang berhak untuk mengeluarkan peraturan menteri, tidak seperti halnya menteri koordinator karena sifatnya hanya kordinasi saja antar kementerian.

Menurut O. Hood Philips yang pendapatnya dikutip oleh Anna Erliana menyatakan baik menteri, pemerintah daerah dan badan-badan publik lainnya, hanya sah melaksanakan wewenangnya dalam batas-batas yang diberikan undang-undang kepada mereka. Keputusan yang dibuat mungkin melebihi wewenang dan menjadi ultra vires karena badan administrasi melakukan transaksi dengan persoalan diluar wewenangnya ini disebut substantif ultra vires, atau karena gagal mengikuti prosedur yang ditentukan maka tindakannya disebut prosedural ultra vires. ${ }^{10}$

Undang-Undang Nomor 39 Tahun 2008 tentang Kementerian Negara menyebutkan bahwa setiap Menteri membidangi urusan tertentu dalam pemerintahan. Urusan tertentu sebagaimana dimaksud Pasal 4 ayat (2) Undang-Undang Nomor 39 Tahun 2008 tentang Kementerian Negara terdiri atas:

a. Urusan pemerintahan yang nomenklatur kementeriannya secara tegas disebutkan dalam Undang-Undang Dasar Negara Republik Indonesia Tahun 1945;

b. Urusan pemerintahan yang ruang lingkupnya disebutkan dalam Undang-Undang Dasar Negara Republik Indonesia Tahun 1945; dan

c. Urusan pemerintahan dalam rangka penajaman, koordinasi, dan sinkronisasi program pemerintah.

\footnotetext{
${ }^{7}$ Maria Farida Indrati. (2007). Ilmu Perundang-undangan, Yogyakarta: Kanisius. hlm. 55

${ }^{8}$ A.Hamid S. Attamimi. (1993). Hukum Tentang Peraturan Perundang-Undangan dan Peraturan Kebijakan (Hukum Tata Pengaturan), Jakarta: Fakutlas Hukum Universitas Indonesia, hlm 45

J J.A.H Logemann dalam Pantja Astawa, dan Suprin Na'a, Dinamika Hukum dan Ilmu Perundang-undangan di Indonesia. (2008), Bandung: Alumni, hlm 66

${ }^{10}$ Anna Erliana. (2007). Hukum Administrasi Negara, Depok: Fakultas Hukum Universitas Indonesia, hlm 65
} 
Jika dikaitkan dengan kedudukan menteri dalam menjalankan kekuasaan pemerintahan dan sebagai upaya melaksanakan urusan pemerintahan yang dibidanginya, maka menteri diberikan kewenangan untuk membentuk perundang-undangan yakni Peraturan Menteri. Hal ini diperkuat dengan pendapat Rosjidi Ranggawidjaja yang

Mengenai kewenangan menteri dalam pembentukan peraturan perundang-undangan pada dasarnya ada dua jenis peraturan perundang-undangan yang dapat ditetapkan oleh menteri, yaitu peraturan menteri dan keputusan menteri. Oleh karena menteri adalah pembantu presiden. Maka para menteri menjalankan kewenangan pemerintahan di bidangnya masingmasing berdasarkan delegasian wewenang (derivatif) dari Presiden. Keputusan presiden tentang pokok-pokok organisasi departemen, misalnya merupakan turunan kewenangan dari Presiden. Keputusan presiden tentang Pokok-Pokok Organisasi Departemen, misalnya merupakan turunan Presiden kepada Menteri-menteri. Untuk materi tertentu, kewenangan tersebut dapat juga diberikan melalui atribusi atau delegasi dari Undang-Undang atau Peraturan Pemerintah. Walaupun dibedakan antara Peraturan Menteri dengan Keputusan menteri (yang berisi pengaturan). Pada kenyataannya tidak jelas materi apa yang harus diatur dengan Peraturan Menteri. Yang pasti bahwa keduanya merupakan peraturan pelaksanaan dari peraturan perundang-undangan yang lebih tinggi.

Undang-Undang Dasar Negara Republik Indonesia Tahun 1945 dan Undang-Undang Nomor 39 Tahun 2008 tidak menyebutkan secara jelas mengenai kewenangan menteri dalam membentuk perundang-undangan. Perundang-undangan yang menyebut mengenai jenis perundangundangan yang dapat dibentuk oleh menteri adalah penjelasan Pasal 8 ayat (1) dan ayat (2) Undang-Undang Nomor 12 Tahun 2011 tentangg Pembentukan Peraturan Perundang-undangan yang menyatakan Peraturan Menteri adalah peraturan yang ditetapkan oleh menteri berdasarkan materi muatan dalam rangka penyelenggaraan urusan tertentu dalam pemerintahan dan penyelenggaraan urusan tertentu pemerintahan sesuai dengan ketentuan Peraturan Perundang-undangan.

Ketidaksinkronan peraturan perundang-undangan membuka celah uji materiil (judicial review) melalui Mahkamah Agung. Peraturan Pemerintah Nomor 9 Tahun 2018 tentang Tata Cara Pengendalian Impor Komoditas Perikanan dan Komoditas Pergaraman dapat diujimateriilkan karena secara materiil substansinya melampaui Undang-Undang Nomor 7 Tahun 2016 tentang Perlindungan dan Pemberdayaan Nelayan, Pembudi Daya Ikan, dan Petambak Garam, khususnya pemberian kewenangan baru kepada Menteri di bidang perindustrian untuk memberikan rekomendasi impor untuk garam bahan baku dan bahan penolong, serta Menteri di bidang Perdagangan untuk melakukan persetujuan impor, yang sebelumnya tidak diatur Undang-Undang Nomor 7 Tahun 2016.

Selain itu, Peraturan Menteri Perdagangan Nomor 63 Tahun 2019 tentang Ketentuan Impor Garam, yang mengatur lebih lanjut mengenai kewenangan persetujuan impor garam oleh Menteri di bidang Perdangangan. Permohonan pengujian peraturan perundangundangan di bawah undang-undang terhadap undang-undang diajukan langsung oleh pemohon atau kuasanya kepada Mahkamah Agung, sebagaimana ditentukan Pasal 31A ayat (1) UndangUndang Nomor 3 Tahun 2009 Tentang Perubahan Kedua Atas Undang-Undang Nomor 14 Tahun 1985 Tentang Mahkamah Agung. Petambak garam dapat melakukan permohonan uji materiil karena uji materiil hanya dapat dilakukan oleh pihak yang menganggap haknya dirugikan oleh berlakunya peraturan perundang-undangan di bawah undang-undang.

Petambak garam merupakan pihak yang secara nyata dirugikan karena adanya ketidakkonsistenan peraturan mengenai impor garam yang diatur dalam Peraturan Menteri Nomor 9 Tahun 2018 dan Peraturan Menteri Perdagangan Nomor 63 Tahun 2019. Kedua 
peraturan ini membuka celah yang lebar bagi impor garam, padahal undang-undang secara tegas memberikan perlindungan dan pemberdayaan bagi petambak garam.

Ketentuan-ketentuan tersebut dapat diartikan bahwa peraturan menteri lahir karena urusan tertentu dalam pemerintahan yakni urusan -urusan yang telah menjadi urusan kementerian itu sendiri dan urusan yang telah ditetapkan oleh peraturan perundang-undangan baik undangundang, peraturan pemerintah maupun peraturan presiden. Namun, tidak semua kementerian mempunyai kewenangan untuk membentuk peraturan menteri, hanya menteri-menteri yang memimpin suatu lembaga saja yang berhak untuk mengeluarkan peraturan menteri, tidak seperti halnya menteri koordinator karena sifatnya hanya kordinasi saja antar kementerian.

Secara teoritis, antinomi hukum khususnya antinomi peraturan perundang-undangan sudah menemukan jalan penyelesaiannya sendiri tanpa harus melalui upaya hukum uji materiil. Untuk menyelesaikan konflik antar norma hukum (antinomi hukum), berlakulah asas-asas penyelesaian konflik. Asas penyelesaian konflik peraturan perundang-undangan merujuk pada asas berlakunya peraturan perundang-undangan. Asas-asas tersebut antara lain:

a. Lex superiori derogat legi inferiori, yaitu peraturan perundang-undangan yang lebih tinggi akan melumpuhkan peraturan perundang-undangan yang lebih rendah;

b. Lex specialis derogat legi generali, yaitu peraturan yang khusus akan melumpuhkan peraturan yang umum sifatnya atau peraturan yang khususlah yang harus didahulukan;

c. Lexposterioriderogatlegipriori,yaituperaturanyangbarumengalahkanataumelumpuhkan peraturan yang lama.

Di samping itu ada langkah praktis untuk menyelesaikan konflik tersebut antara lain pengingkaran (disavowal), reinterpretasi, pembatalan (invalidation), dan pemulihan (remedy). Dalam hal menghadapi norma hukum yang kabur atau norma yang tidak jelas, hakim menafsirkan undang-undang untuk menemukan hukumnya. Penafsiran oleh hakim merupakan penjelasan yang harus menuju kepada pelaksanaan yang dapat diterima oleh masyarakat mengenai peraturan hukum terhadap peristiwa konkrit. Metode interpretasi adalah saran atau alat untuk mengetahui makna undang-undang.

\section{KESIMPULAN}

Antinomi hukum merupakan hal yang wajar menurut teori antinomi. Namun, antinomi hukum khususnya antinomi peraturan perundang-undangan di bidang impor garam berimplikasi secara empiris pada perlindungan petambak garam dan produksi garam lokal. Selain itu, antinomi menyebabkan terbukanya celah yang lebar mengenai impor komoditas garam yang dapat dilihat dari jenis garam yang dapat diimpor, dan tarik menarik kewenangan kementerian negara yang berwenang memberikan rekomendasi dan persetujuan impor. Di satu sisi, kewenangan rekomendasi impor semula hanya dimiliki oleh Kementerian Kelautan dan Perikanan berdasarkan Undang-Undang Nomor 7 Tahun 2016 tentang Perlindungan dan Pemberdayaan Nelayan, Pembudi Daya Ikan, dan Petambak Garam. Di sisi lain, Peraturan Pemerintah Nomor 9 Tahun 2018 tentang Tata Cara Pengendalian Impor Komoditas Perikanan dan Komoditas Pergaraman sebagai Bahan Baku dan Bahan Penolong Industri memberikan kewenangan kepada Menteri Perindustrian untuk memberikan rekomendasi impor garam bahan baku dan bahan penolong, serta Peraturan Menteri Perdagangan Nomor 63 Tahun 2019 yang memberikan kewenangan kepada Menteri Perdangangan untuk memberikan persetujuan impor garam bahan baku, bahan penolong, maupun garam lainnya.

Norma baru yang dibentuk pada Peraturan Pemerintah dan Peraturan Menteri sudah melanggar ketentuan Pasal 5 ayat (2) Undang-Undang Dasar Negara Republik Indonesia Tahun 1945, bahwa Peraturan Pemerintah dibentuk hanya untuk melaksanakan ketentuang undang-undang. Ketidakkonsistenan regulasi dalam rangka pengendalian impor yang bertujuan 
melindungi petambak garam masih terjadi. Peraturan Menteri Kelautan dan Perikanan Nomor 66/PERMEN-KP/2017 tentang Pengendalian Impor Komoditas Pergaraman mencoba memberikan perlindungan bagi petambak garam dengan memberikan kewajiban bagi importir garam untuk memprioritaskan penyerapan garam dari dalam negeri, tetapi Peraturan Menteri Perdagangan Nomor 63 Tahun 2019 membuka celah impor garam dengan memaksukkan semua jenis garam dapat diimpor.

Antinomi peraturan perundang-undangan di bidang impor garam nasional dapat diselesaikan melalui penerapan asas berlakunya perundang-undangan lex superior degogat legi inferior. Peraturan Pemerintah Nomor 9 Tahun 2018 tentang Tata Cara Pengendalian Impor Komoditas Perikanan dan Komoditas Pergaraman Sebagai Bahan Baku Dan Bahan Penolong Industri dan Peraturan Menteri Perdagangan Nomor 63 Tahun 2019 tentang Ketentuan Impor Garam harus dikesampingkan keberlakuannya. Yang berlaku adalah Undang-Undang Nomor 7 Tahun 2016 tentang Perlindungan dan Pemberdayaan Nelayan, Pembudi Daya Ikan, dan Petambak Garam.

Namun, penyelesaian secara teoritis akan menemui kendala dalam tataran praktis. Oleh karena itu, upaya hukum berupa uji materiil ke Mahkamah Agung. mengenai Pemerintah Nomor 9 Tahun 2018 tentang Tata Cara Pengendalian Impor Komoditas Perikanan dan Komoditas Pergaraman sebagai Bahan Baku dan Bahan Penolong Industri dan Peraturan Menteri Perdagangan Nomor 63 Tahun 2019 tentang Ketentuan Impor Garam, yang dinilai bertentangan dengan Undang-Undang Nomor 7 Tahun 2016 tentang Perlindungan Dan Pemberdayaan Nelayan, Pembudi Daya Ikan, dan Petambak Garam. Uji materiil diajukan oleh Petambak Garam atau Komunitas Petambak Garam.

\section{Daftar Pustaka}

A.Hamid S. Attamimi.(1993). Hukum Tentang Peraturan Perundang-Undangan dan Peraturan Kebijakan (Hukum Tata Pengaturan), Jakarta: Fakutlas Hukum Universitas Indonesia.

Anna Erliana. (2007). Hukum Administrasi Depok: Fakultas Hukum Universitas Indonesia.

David Hume. (2009). A Treaties of Human Nature. Auckland: The Floating Press.

Immanuel Kant. (2010). Critique of Pure Reason. Cambridge University Press

J.A.H Logemann dalam Pantja Astawa, dan Suprin Na'a, Dinamika Hukum dan Ilmu Perundang-undangan di Indonesia. (2008), Bandung: Alumni.

Johny Ibrahim, Teori dan Metodologi Penelitian Hukum Normatif (Malang: Banyumedia Publishing, 2006).

Maria Farida Indrati. (2007). Ilmu Perundang-undangan, Yogyakarta: Kanisius.

Soerjono Soekanto dan Sri Mamudji. (2006). Penelitian Hukum Normatif Tinjauan Singkat. Jakarta: Rajawali Press.

Sudikno Mertokusumo. (1996). Penemuan Hukum Suatu Pengantar. Yogyakarta: Liberty.

W. Friedman. (1990). Teori dan Filsafat Hukum, Telaah Kritis atas Teori-teori Hukum (Susunan II). Penerjemah Arifin, M. Jakarta: Rajawali Press.

Torben Spaak, "Meta-Ethic and Legal Theory: The Case of Gustav Radbruch", Jurnal Law and Philosophy, 28(3)

M. Ambari, "https://www.mongabay.co.id/2017/08/29/bangkit-dari-keterpurukan-indonesiatargetkan-swasembada-garam-pada-2019-bagaimana-strateginya/", diakses 03 November 2020.

36 Laurensia Frida Alfiani | Antinomi Peraturan Perundang-Undangan... 
M. Ambari, “https://www.mongabay.co.id/2018/04/30/garam-rakyat-didorong-penuhistandar-internasional-bagaimana-caranya/", diakses 03 November 2020. 